ORIGINAL ARTICLE

\title{
Impact of an acute heat shock during in vitro maturation on interleukin 6 and its associated receptor component transcripts in bovine cumulus-0ocyte complexes
}

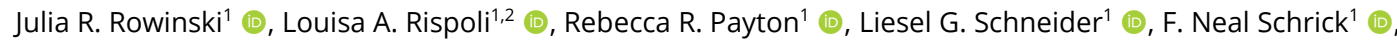 \\ Kyle J. McLean ${ }^{1}$ (i), J. Lannett Edwards ${ }^{1 *}$ (1) \\ ${ }^{1}$ Department of Animal Science, The University of Tennessee, Institute of Agriculture, AgResearch, Knoxville, TN, USA \\ ${ }^{2}$ Cincinnati Zoo \& Botanical Garden, Cincinnati, OH, USA
}

How to cite: Rowinski JR, Rispoli LA, Payton RR, Schneider LG, Schrick FN, McLean KJ, Edwards JL. Impact of an acute heat shock during in vitro maturation on interleukin 6 and its associated receptor component transcripts in bovine cumulusoocyte complexes. Anim Reprod. 2020;17(4):e20200221. https://doi.org/10.1590/1984-3143-AR2020-0221

\begin{abstract}
An acute heat stress event after the LH surge increased interleukin 6 (IL6) levels in the follicular fluid of the ovulatory follicle in hyperthermic cows. To examine direct consequences of a physiologically-relevant elevated temperature $\left(41.0^{\circ} \mathrm{C}\right)$ on the cumulus-oocyte complex (COC), IL6 transcript abundance and related receptor components were evaluated throughout in vitro maturation. Heat-induced increases in IL6 were first noted at 4 hours of in vitro maturation (hIVM); peak levels occurred at 4.67 versus 6.44 hIVM for 41.0 and $38.5^{\circ} \mathrm{C} \mathrm{COCs}$, respectively (SEM $=0.23 ; \mathrm{P}<0.001$ ). Peak IL6ST levels occurred at 6.95 versus $8.29 \mathrm{hIVM}$ for 41.0 and $38.5^{\circ} \mathrm{C}$, respectively (SEM $=0.23 ; \mathrm{P}<0.01$ ). Transcript for LIF differed over time $(\mathrm{P}<0.0001)$ but was not affected by $41.0^{\circ} \mathrm{C}$ exposure. Blastocyst development after performing IVF was not affected by $41.0^{\circ} \mathrm{C}$ exposure for 4 or $6 \mathrm{~h}$. When limiting analysis to when IL6 was temporally produced, progesterone levels were only impacted by time and temperature (no interaction). Heat-induced shift in the temporal production of IL6 and IL6ST along with its impact on progesterone likely cooperate in heat-induced hastening of meiotic progression described by others.
\end{abstract}

Keywords: cumulus-oocyte complex, heat shock, Interleukin 6, oocyte maturation, progesterone.

\section{Introduction}

Dairy cows lose the ability to maintain body temperature when temperature-humidity index approaches 72 (Armstrong, 1994). In moderate to severe instances of environmental heat stress, cow body temperature may reach or exceed $41.0^{\circ} \mathrm{C}$ (Gaalaas, 1945 ; Seath and Miller, 1946; Roman-Ponce et al., 1977; Turner, 1982; Elvinger et al., 1991; Ealy et al., 1993). This level of hyperthermia is problematic because for each $1^{\circ} \mathrm{C}$ increase in rectal temperature pregnancy rate decreases by $\sim 25 \%$ (Ulberg and Burfening, 1967). Hyperthermia occurring at or near the time of breeding during chronic periods of heat stress is especially problematic. Cows having elevated rectal temperatures before artificial insemination are more likely to return to service and have lower conception rates (Fallon, 1962). Hyperthermia related decreases in fertility are not limited to Holstein cows but are problematic in other breeds (Dunlap and Vincent, 1971), and even Bos indicus cattle (Zakari et al., 1981).

*Corresponding author: jedwards@utk.edu

Received: September 1, 2020. Accepted: December 3, 2020.

Financial support: JLE received funding for this research from the Agriculture and Food Research Initiative Competitive Grant $\mathrm{n}^{\circ}$. 2016-67015-24899 from the USDA National Institute of Food and Agriculture, the state of Tennessee through UT AgResearch, East Tennessee Research and Education Center, the Department of Animal Science, and the USDA National Institute of Food and Agriculture, Hatch Project n 1015707 and 1022068.

Conflicts of interest: The authors have no conflict of interest to declare.

(c) (i) Copyright (c) The Author(s). This is an Open Access article distributed under the terms of the Creative Commons Attribution License, which permits unrestricted use, distribution, and reproduction in any medium, provided the original work is properly cited. 
Mechanisms underlying heat-induced reductions in fertility are multifactorial, and to some extent relate to direct effects of elevated body temperature on maternal environment (e.g., ovulatory follicle components) and the cumulus-oocyte complex (COC) resident within (Edwards and Hansen, 1996; Lawrence et al., 2004; Zhandi et al., 2009). Related to impacting ovulatory follicle components, Rispoli et al. (2019) examined the follicular fluid proteome of lactating dairy cows that became hyperthermic as a result of an acute heat stress event occurring after a pharmacologically-induced LH surge. Hyperthermic cows had increased levels of IL6 in the follicular fluid of the ovulatory follicle (Rispoli et al., 2019). Because circulating levels were similar in cows maintained in thermoneutral and heat stress conditions (Rispoli et al., 2019), we hypothesized that heat-induced increases in follicular fluid levels of IL6 likely originated from ovulatory follicle components. In support of this notion, IL6 is produced by the mural granulosa cells (murine: (Liu et al., 2009), porcine: (Faundez et al., 2015)) and the cumulus-oocyte complex (human: (Zolti et al., 1991; Machelon et al., 1994), murine: (Liu et al., 2009), ovine: (Zhao et al., 2012), bovine: (Tscherner et al., 2018)).

Towards functional significance, Liu et al. (2009) showed that the addition of IL6 to murine COCs during in vitro maturation improved success of embryo transfers by increasing number of pups born. Other efforts using ovine (Zhao et al., 2012), bovine (Faundez et al., 2014) and porcine (Faundez et al., 2015) COCs noted improvements in meiotic progression (i.e., metaphase I or metaphase II) with the IL6 addition to the maturation medium. Effects of IL6 appear dose dependent when added during in vitro maturation. Zhao et al. (2012) demonstrated that a lower dose of IL6 $(10 \mathrm{ng} / \mathrm{mL})$ increased maturation rates of ovine COCs, whereas a higher dose $(100 \mathrm{ng} / \mathrm{mL})$ reduced maturation rates and impaired subsequent embryo development.

Mindful of effects to promote meiotic maturation (murine: (Liu et al., 2009), bovine: (Faundez et al., 2014), porcine: (Faundez et al., 2015)) and cumulus expansion (murine: (Liu et al., 2009; Wang et al., 2014), human: (Clark et al., 2011), porcine: (Faundez et al., 2015)), initial efforts of study one focused on examining IL6 abundance in the cumulus-oocyte complex throughout in vitro maturation when directly exposed to the physiologically-relevant elevated temperature of $41.0^{\circ} \mathrm{C}$. Because receptor mediated signaling is dependent on forming a complex with the IL6 signal transducer (Hibi et al., 1990; Mackiewicz et al., 1992; Heinrich et al., 2003; Wolf et al., 2014), the relative abundance of the IL6 receptor and its associated signal transducer (IL6ST) was also examined in COCs throughout in vitro maturation. Noting that a major consequence of $41.0^{\circ} \mathrm{C}$ exposure at the beginning of maturation was to shift the temporal production of IL6ST, additional effort was put forth to examine the relative abundance of another member of the IL6 family of cytokines (i.e., leukemia inhibitory factor; LIF). After receptor binding, IL6ST is also utilized for LIF based-signal transduction (Gearing et al., 1991; Tscherner et al., 2018). Like IL6, LIF has been shown by others to affect oocyte maturation (Dang-Nguyen et al., 2014; Mo et al., 2014; Wang et al., 2019).

\section{Materials and methods}

\section{Collection and in vitro maturation of bovine cumulus-oocyte complexes}

Reagents and chemicals were obtained from MilliporeSigma (St. Louis, MO, USA) unless indicated otherwise. Oocytes were collected from abattoir-derived ovaries (Lawrence et al., 2004) located in Gaffney, South Carolina, USA (Brown Packing Co., Inc). Media were prepared per Rispoli et al. (2011). Folltropin-V (FSH) was obtained from Vetrepharm Canada, INC. (London, ON, Canada); same batch was used throughout. Cumulus-oocyte complexes with compact cumulus cell vestments and homogenous ooplasm underwent in vitro maturation (Study 1: 30 COCs per $0.5 \mathrm{ml}$ maturation medium in polystyrene tubes; Sarstedt AG and Co., Nümbrecht, Germany; Study 2: 29 to 45 COCs (mean = 34.3 \pm 0.66 ) per $0.5 \mathrm{~mL}$ in 4-well Nunc culture dishes; Thermo Fisher Scientific, Waltham, MA, USA). Incubator temperatures were verified before and during different studies using mercury thermometers sealed in media-filled bottles. 


\section{Study one: Interleukin 6, IL6 receptor, signal transducer and LIF transcripts during in vitro maturation in COCs matured at 38.5 or $41.0^{\circ} \mathrm{C}$}

Cumulus-oocyte complexes were matured at 38.5 or $41.0^{\circ} \mathrm{C}$ (exposure to $41.0^{\circ} \mathrm{C}$ was restricted to first $12 \mathrm{~h}$ only; thereafter $\mathrm{COCs}$ were transferred to $38.5^{\circ} \mathrm{C}$ ). At $2,4,6,8,10,12,16$, 20 and $24 \mathrm{~h}$ in vitro maturation (hIVM) subsets of COCs were removed from culture and kept separate by treatment (Figure 1;2 $\times 9$ factorial treatment arrangement). A subset of COCs was also processed soon after removal from ovary to provide a 0 hIVM group. Per each time period, COCs were washed twice in Dulbecco's phosphate buffered saline containing $0.1 \%$ polyvinyl alcohol and pelleted ( $600 \times \mathrm{g}$, $5 \mathrm{~min})$. After supernatant removal, COCs were lysed in extraction buffer (Quick-RNA Kit; Zymo Research, Irvine, CA, USA) and stored at $-80^{\circ} \mathrm{C}$ until RNA isolation. Maturation medium that was conditioned by COCs during culture was centrifuged ( $5 \mathrm{~min}, 3000$ $\mathrm{x}$ g); supernatant was stored at $-20^{\circ} \mathrm{C}$. Cumulus-oocyte complexes were collected from ovaries on four different days with 3,840 total COCs being utilized. On a given day's collection, two different pools of $30 \mathrm{COCs}$ matured at 38.5 and $41^{\circ} \mathrm{C}$ were evaluated at $0,4,8,12,16,20$, and 24 hIVM resulting in a total of 8 observations per these treatment combinations. Related to 2 , 6 , and $10 \mathrm{hIVM}$, only one group of $30 \mathrm{COCs}$ were matured at 38.5 and $41^{\circ} \mathrm{C}$ resulting in a total of 4 observations for each of these time periods.

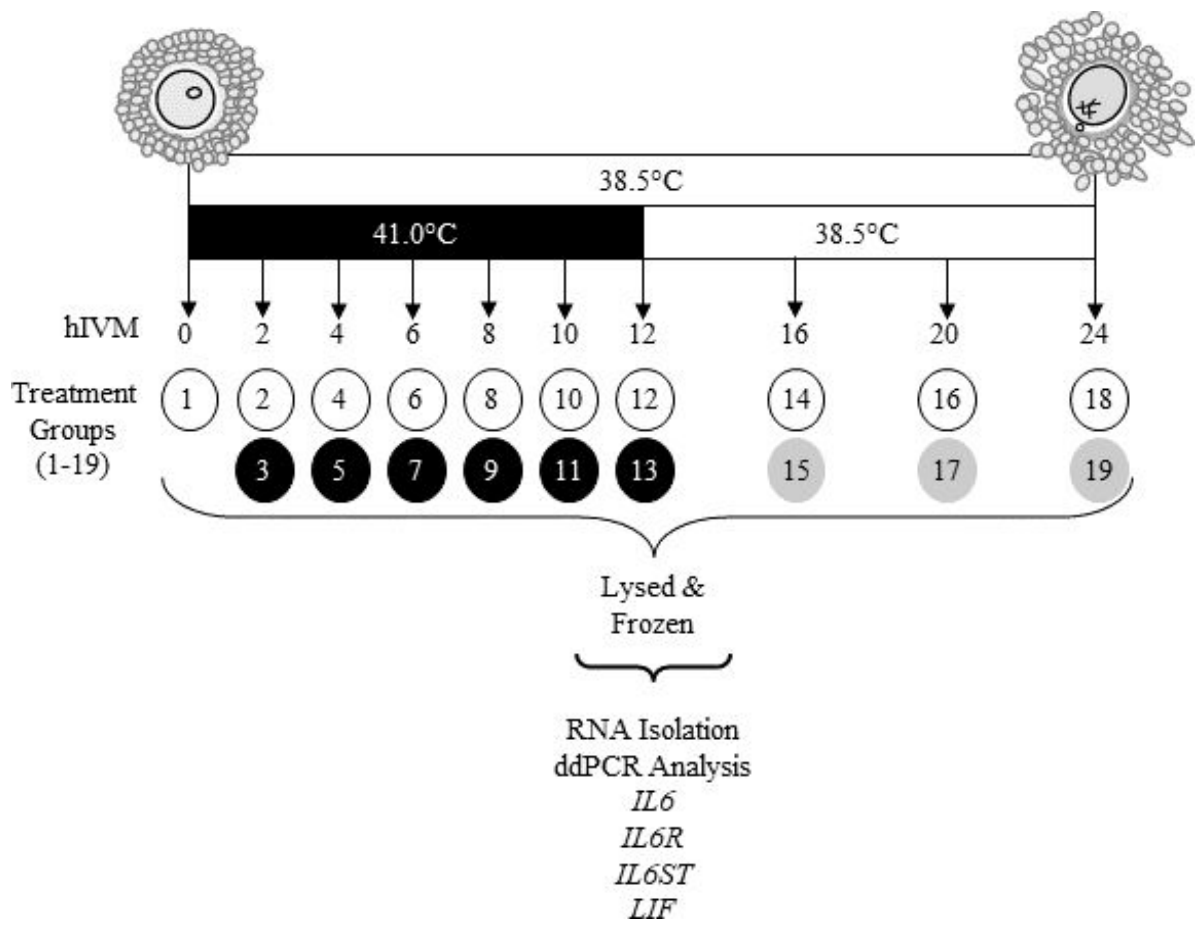

Figure 1. Schematic of study design. At $2,4,6,8,10,12,16,20$, or 24 hIVM subsets of COCs matured at $38.5^{\circ} \mathrm{C}$ (designated by white circles) or $41.0^{\circ} \mathrm{C}$ (first 12 designated by black circles, then moved to $38.5^{\circ} \mathrm{C}$ designated by gray circles) were removed from culture, washed, lysed before storage at $-80^{\circ} \mathrm{C}$ until RNA extraction and subsequent RNA analyses.

\section{Total RNA isolation, cDNA synthesis, primer design and ddPCR}

Total COC RNA was isolated using the Quick-RNA Microprep Kit (Zymo Research, Irvine, CA, USA) with on-column DNAse treatment per manufacturer. Quantity (Nanodrop ND-1000; NanoDrop Technologies, USA) and quality (RNA Nano LabChip; Bioanalyzer 2100, Agilent, USA) of total RNA were determined (RIN values ranged from 7.2 to 10; median of 8.9). Reverse transcription with oligo (dT) and random primers (500 ng per 20 ul reaction; iScript Reverse Transcription Supermix, Bio-Rad, Hercules, CA, USA) was performed per manufacturer and diluted 5-fold with $1 \mathrm{mM}$ Tris- $\mathrm{HCl}(\mathrm{pH} 8.0)$ and $0.01 \mathrm{mM}$ EDTA (0.1X TE) before performing digital droplet polymerase chain reactions (ddPCR) analyses. A pool resulting from all samples within each collection day was sham-transcribed (iScript No-RT Control Supermix, Bio-Rad) as an additional control. 
Primer-BLAST (National Center for Biotechnology Information; U.S. National Library of Medicine, Bethesda, MD, USA) was utilized to design primers spanning exon-exon junction and/or introns (Table 1). Resulting amplicons were evaluated via gel electrophoresis and sequenced to ensure single product with correct specificity. As per manufacturer guidelines, a gradient of primer concentrations and annealing temperatures were tested to determine optimal conditions (Table 1) that would maximize fluorescent intensity between positive and negative droplets while minimizing occurrence of off-target and/or non-specific amplification events (i.e., rain). Digital droplet PCR was performed in duplicate using 10 ng of nucleic acid per reaction per manufacturer's instructions. No template controls (NTC; 0.1X TE) were analyzed to assess background signal and control for exogenous contamination. Samples were amplified for 40 cycles, 30s per conditions in Table 1 followed by signal stabilization $\left(4^{\circ} \mathrm{C}\right.$ for $5 \mathrm{~min}, 40^{\circ} \mathrm{C}$ for $5 \mathrm{~min}$, hold at $12^{\circ} \mathrm{C}$ ). Acquired data were analyzed using QuantaSoft Analysis Pro (ver. 1.0, Bio-Rad) to calculate number of copies per $\mu$.

Table 1. Primer sequences and annealing conditions used for ddPCR.

\begin{tabular}{|c|c|c|c|c|c|}
\hline Gene & $\begin{array}{c}\text { GenBank } \\
\text { Accession } \\
\text { Number }\end{array}$ & $\begin{array}{c}\text { Amplicon } \\
\text { Location } \\
\text { (bp) }\end{array}$ & Primer Set & $\begin{array}{c}\text { Primer } \\
\text { Concentration } \\
\text { (nM) }\end{array}$ & $\begin{array}{c}\text { Annealing } \\
\text { Temperature } \\
\left({ }^{\circ} \mathrm{C}\right)\end{array}$ \\
\hline \multirow{2}{*}{ IL6 } & \multirow{2}{*}{ NM_173923.2 } & \multirow{2}{*}{$349-568$} & 3'-GCATCTTCTCCAGCAGGTCAG & \multirow{2}{*}{250} & \multirow{2}{*}{56} \\
\hline & & & 5'-CAATCTGGGTTCAATCAGGCGAT & & \\
\hline \multirow{2}{*}{ IL6R } & \multirow{2}{*}{ NM_001110785.3 } & \multirow{2}{*}{$343-666$} & 3'-TCGGGCTGTAGGAGTTTGTAGC & \multirow{2}{*}{125} & \multirow{2}{*}{56} \\
\hline & & & 5'-GCGCTTGGTGGTGGATGTTC & & \\
\hline \multirow{2}{*}{ IL6ST } & \multirow{2}{*}{ XM_010816769.3* } & \multirow{2}{*}{$\begin{array}{l}1136- \\
1355\end{array}$} & 3'-CGCGTCTGATTTGCCAACAA & \multirow{2}{*}{250} & \multirow{2}{*}{58} \\
\hline & & & 5'-GTCTCATGCTCACGGCACTA & & \\
\hline \multirow{2}{*}{ LIF } & \multirow{2}{*}{ NM_173931 } & \multirow{2}{*}{$157-359$} & 3'-CTGGGCCGTGTAATAGAGGAT & \multirow{2}{*}{250} & \multirow{2}{*}{58} \\
\hline & & & 5'-TCTTGGCGGCAGGAGTTGT & & \\
\hline \multirow{2}{*}{ SDHA } & \multirow{2}{*}{ NM_174178 } & \multirow{2}{*}{$\begin{array}{c}1433- \\
1646\end{array}$} & 3'-TCCGTAGAGGCTGCTGATCT & \multirow{2}{*}{250} & \multirow{2}{*}{58} \\
\hline & & & 5'-GTCCTGCAGACCCGGAGATA & & \\
\hline
\end{tabular}

*Wooldridge and Ealy (2019).

Transcript abundance was normalized to succinate dehydrogenase A (SDHA). Succinate dehydrogenase $A$ has been used as a normalizer for in vivo and in vitro matured COCs (Assidi et al., 2010; Macabelli et al., 2014; del Collado et al., 2017; Botigelli et al., 2018) and for heat-stressed COCs (Pavani et al., 2017). It is stably expressed in cumulus during maturation (Assidi et al., 2010; Regassa et al., 2011).

\section{Progesterone production}

Progesterone released into the maturation medium by COCs matured at 38.5 or $41.0^{\circ} \mathrm{C}$ (Figure 1) was analyzed by radioimmunoassay per manufacturer's instructions (Double Antibody RIA; MP Biomedicals, Santa Ana, CA., USA). Assay sensitivity was $0.02 \mathrm{ng} / \mathrm{mL}$; inter- and intra-assay coefficients of variation were 7.6 and $6.0 \%$, respectively.

\section{Study two: embryo development after COC exposure to $41.0^{\circ} \mathrm{C}$ for first 4 or 6 hIVM}

Because heat-induced increases in IL 6 levels were noted by 4 hIVM and by 4 and 6 hIVM for IL6ST, a second study was performed to evaluate consequences of a $41.0^{\circ} \mathrm{C}$ exposure for 4 or $6 \mathrm{~h}$ on embryonic development. Cumulus-oocyte complexes meeting criteria described above were randomly allocated to three different treatment groups: $38.5^{\circ} \mathrm{C}$ for $24 \mathrm{hIVM}, 41.0^{\circ} \mathrm{C}$ for $4 \mathrm{hIVM}$, or $41.0^{\circ} \mathrm{C}$ for 6 hIVM. After 4 or 6 hIVM at $41.0^{\circ} \mathrm{C}$, COCs were transferred to $38.5^{\circ} \mathrm{C}$ for remainder of in vitro maturation. After a total of $24 \mathrm{hIVM}$, a combination of frozen-thawed-washed sperm from two bulls was added at $\sim 500,000$ motile sperm $/ \mathrm{ml}$ to each well of COCs. Presumptive zygotes were 
denuded of cumulus and associated sperm at $\sim 16$ to $18 \mathrm{~h}$ after addition of sperm. Embryonic cleavage was assessed 66 to $70 \mathrm{~h}$ after addition of sperm at which point essential amino acids were added to culture medium. At 172 to $178 \mathrm{~h}$ after addition of sperm, blastocyst development was recorded. Blastocyst stage and quality scoring was performed as described by Schrock et al. (2007). Number of nuclei was assessed using fluorescent microscopy (40X magnification using a Nikon Eclipse TE300; UV-2A filter: ex 330 to 380 nm, em 400 to 420 nm; Nikon Instruments, Melville, NY, USA) after fixation in 3\% paraformaldehyde. Thereafter, embryos were stained using $5 \mu \mathrm{g} / \mathrm{ml}$ Hoechst 33342, washed, and then mounted on glass slides in Dulbecco's phosphate buffered saline containing $50 \%$ glycerol and $0.5 \mu \mathrm{g} / \mathrm{ml}$ Hoechst 33342. For this study, COCs were collected from ovaries on five different days with total of 1,338 COCs being utilized.

\section{Statistical analyses}

A randomized complete block design was implemented for study one. Data were analyzed using generalized linear mixed models (PROC GLIMMIX, SAS 9.4, SAS Institute, Cary, NC, USA) blocking on day of COC collection. Mindful of the $2 \times 9$ factorial treatment arrangement, fixed effects in the model included IVM temperature $\left(38.5\right.$ and $\left.41.0^{\circ} \mathrm{C}\right)$, IVM time $(2,4,6,8,10,12,16$, 20 and $24 \mathrm{~h}$ ), and respective interaction (IVM temperature $\times$ IVM time; 18 treatment combinations). Treatment differences were determined using Fishers-protected least significant differences and are reported as least squares means \pm standard error.

Multisource nonlinear mixed model regression (JMP PRO 14, SAS Institute) was performed a posteriori to determine the extent to which maturation of COCs at $41.0^{\circ} \mathrm{C}$ shifted the timing of changes in transcript abundance compared to levels observed in COCs matured at $38.5^{\circ} \mathrm{C}$. The nonlinear prediction model fit was: $a \times e^{-\left(0.5 \times\left(\frac{h V M-b}{c}\right)^{2}\right)}$ where $a$ is peak (highest) value, $b$ is when peak value occurred, and $c$ is growth rate (width of temporal production).

Study two implemented a randomized complete block design; mixed model analysis of variance (PROC GLIMMIX; SAS 9.4) was utilized to test the main effect of treatment while blocking on the random effect of day of oocyte collection. Treatment differences were determined using Fishers-protected least significant differences.

\section{Results}

\section{Study one: Interleukin 6, IL6 receptor, signal transducer and LIF transcripts during in vitro maturation in COCs matured at 38.5 or $41.0^{\circ} \mathrm{C}$}

\section{Relative abundance of IL6 in COCs matured at 38.5 and $41.0^{\circ} \mathrm{C}$}

Abundance of IL6 transcript differed depending upon IVM temperature and hIVM (Temp $x$ hIVM interaction, $\mathrm{P}<0.0001$; Figure $2 \mathrm{~A}$ ). While barely detectable soon after COC collection (0 hIVM), IL6 abundance at $2 \mathrm{hIVM}$ was similar between COCs matured at 38.5 and $41.0^{\circ} \mathrm{C}$. By $4 \mathrm{hIVM}$, acute exposure to $41.0^{\circ} \mathrm{C}$ increased relative abundance of $/ L 6$ transcript compared to $38.5^{\circ} \mathrm{C}$. Interestingly, by 6 and 8 hIVM the relative abundance of $I L 6$ in COCs exposed to $41.0^{\circ} \mathrm{C}$ was lower than that observed in COCs matured at $38.5^{\circ} \mathrm{C}$. By $12 \mathrm{hIVM}$, relative abundance of $/ L 6$ was similar between 41.0 and $38.5^{\circ} \mathrm{C} \mathrm{COCs}$, levels remained low for remainder of maturation.

Use of multisource nonlinear mixed model regression showed that the major consequence of $41.0^{\circ} \mathrm{C}$ exposure at the beginning of maturation was to shift the temporal production of IL6. To this end, IL6 levels peaked at $4.67 \mathrm{hIVM}$ in COCs directly exposed to $41.0^{\circ} \mathrm{C}$, whereas $/ \mathrm{L} 6$ levels peaked at $6.44 \mathrm{hIVM}$ when COCs were matured at $38.5^{\circ} \mathrm{C}(P<0.001$; Figure $2 \mathrm{~A}$, Table 2 ). Peak values and growth rate were similar in COCs matured at 38.5 and $41.0^{\circ} \mathrm{C}$ (Table 2). 

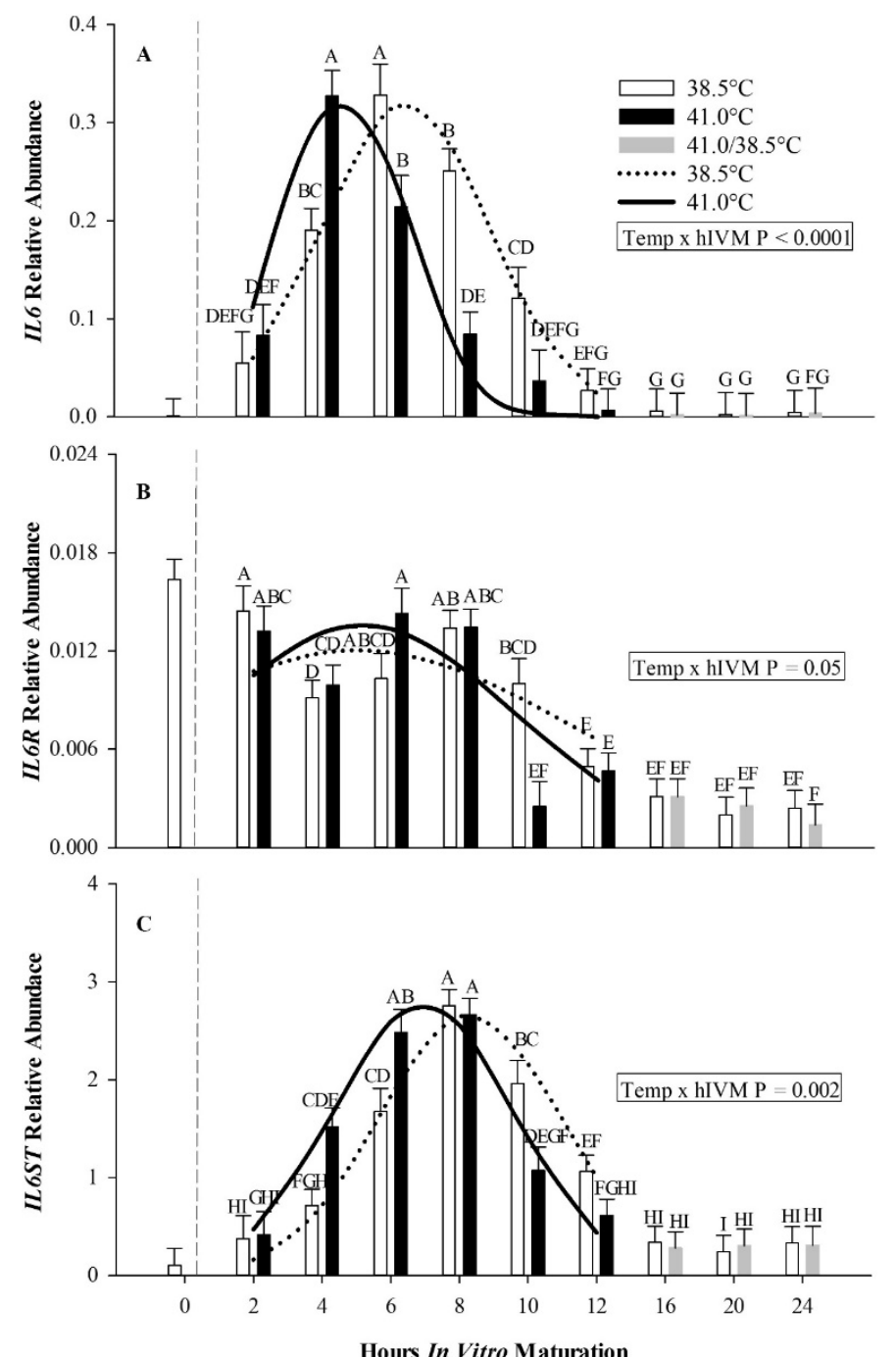

Figure 2. Relative abundance of interleukin 6 and signaling molecules in cumulus-oocyte complexes matured for up to $24 \mathrm{~h}$ at either $38.5^{\circ} \mathrm{C}$ or $41.0^{\circ} \mathrm{C}$ (first $12 \mathrm{~h} ; 38.5^{\circ} \mathrm{C}$ thereafter). Interaction of temperature $\mathrm{x}$ hIVM between $38.5^{\circ} \mathrm{C}$ and $41.0^{\circ} \mathrm{C}$ for IL6 (Panel A), IL6R (Panel B), IL6ST (Panel C). Bars (least squares means \pm SEM) having different letter designations ${ }^{A-1}$ differ at indicated $P$ value (Temp $\times$ hIVM). Dashed $\left(38.5^{\circ} \mathrm{C}\right)$ and solid $\left(41.0^{\circ} \mathrm{C}\right)$ lines indicate relative abundance curves over the first $12 \mathrm{hIVM}$.

Table 2. Impact of $41.0^{\circ} \mathrm{C}$ exposure on IL6, IL6R and IL6ST levels in COCs during in vitro maturation using multisource nonlinear mixed model regression.

\begin{tabular}{|c|c|c|c|c|}
\hline Transcript & & Peak Value* & Peak Time (hIVM) & Growth Rate** \\
\hline \multirow[t]{5}{*}{ IL6 } & $38.5^{\circ} \mathrm{C}$ & $0.32 \pm 0.03^{a}$ & $6.44 \pm 0.23^{a}$ & $2.43 \pm 0.28^{a}$ \\
\hline & $41.0^{\circ} \mathrm{C}$ & $0.33 \pm 0.03^{a}$ & $4.67 \pm 0.23^{b}$ & $1.82 \pm 0.22^{\mathrm{a}}$ \\
\hline & P-value & $P>0.05$ & $P<0.001$ & $P>0.05$ \\
\hline & $\mathrm{R}^{2}$ & 0.67 & & \\
\hline & SSE & 0.41 & & \\
\hline \multirow[t]{5}{*}{ IL6R } & $38.5^{\circ} \mathrm{C}$ & $0.01 \pm 0.00^{\mathrm{a}}$ & $5.02 \pm 1.49^{a}$ & $6.33 \pm 2.01^{a}$ \\
\hline & $41.0^{\circ} \mathrm{C}$ & $0.01 \pm 0.00^{\mathrm{a}}$ & $5.16 \pm 0.70^{a}$ & $4.42 \pm 0.82^{a}$ \\
\hline & P-value & $P>0.05$ & $P>0.05$ & $P>0.05$ \\
\hline & $\mathrm{R}^{2}$ & 0.33 & & \\
\hline & SSE & 0.001 & & \\
\hline \multirow[t]{5}{*}{ IL6ST } & $38.5^{\circ} \mathrm{C}$ & $2.66 \pm 0.19^{a}$ & $8.29 \pm 0.23^{a}$ & $2.66 \pm 0.22^{a}$ \\
\hline & $41.0^{\circ} \mathrm{C}$ & $2.77 \pm 0.20^{a}$ & $6.95 \pm 0.23^{b}$ & $2.63 \pm 0.23^{a}$ \\
\hline & P-value & $P>0.05$ & $P<0.01$ & $P>0.05$ \\
\hline & $\mathrm{R}^{2}$ & 0.69 & & \\
\hline & SSE & 22.7 & & \\
\hline
\end{tabular}

*Peak value: highest obtained level; **Growth rate: Full Width Half Maximum (3 standard deviations from the mid-point at half maximum). ${ }^{\mathrm{a}, \mathrm{b}}$ means differ $\mathrm{P}<0.05$. 


\section{Relative abundance of IL6 receptor (IL6R) in COCs matured at 38.5 and $41.0^{\circ} \mathrm{C}$}

Relative abundance of IL6R differed depending on hIVM and IVM temperature (Temp $\mathrm{x}$ hIVM interaction, $\mathrm{P}=0.05$; Figure $2 \mathrm{~B}$ ). Abundance of IL6R was highest during the first 8 hIVM with abundance decreasing thereafter and reaching lowest levels by 20 to $24 \mathrm{hIVM}$. Except for the 10 hIVM time period, IL6R levels were similar in COCs matured at 38.5 and $41.0^{\circ} \mathrm{C}$ (Figure $2 \mathrm{~B}$, Table 2).

\section{Relative abundance of IL6 Signal Transducer (IL6ST) in COCs matured at 38.5 and $41.0^{\circ} \mathrm{C}$}

Relative abundance of IL6ST transcripts differed depending on IVM temperature and hIVM (Temp $x$ hIVM interaction, $\mathrm{P}=0.002$; Figure $2 \mathrm{C}$ ). While barely detectable in COCs soon after collection from antral follicles, IL6ST abundance at 2 hIVM was similar between COCs matured at 38.5 and $41.0^{\circ} \mathrm{C}$. However, by 4 and $6 \mathrm{hIVM}, 41.0^{\circ} \mathrm{C}$ exposure resulted in higher levels of IL6ST compared to $38.5^{\circ} \mathrm{C}$ counterparts. At $8 \mathrm{hIVM}$ relative abundance of IL6ST in COCs matured at $41.0^{\circ} \mathrm{C}$ was similar to COCs matured at $38.5^{\circ} \mathrm{C}$. By $10 \mathrm{hIVM}$, IL6ST was lower in COCs matured at $41.0^{\circ} \mathrm{C}$ compared to those matured at $38.5^{\circ} \mathrm{C}$. By $16 \mathrm{hIVM}$, relative abundance of IL6ST was similar between 41.0 and $38.5^{\circ} \mathrm{C}$ and equivalent to levels observed at the onset of maturation (i.e., 2 hIVM).

Use of multisource nonlinear mixed model regression showed that the major consequence of $41.0^{\circ} \mathrm{C}$ exposure at the beginning of maturation was to shift the temporal production of IL6ST. To this end, IL6ST peak levels occurred at $6.95 \mathrm{hIVM}$ when COCs were matured at $41.0^{\circ} \mathrm{C}$, whereas peak values were noted at 8.29 hIVM when COCs were matured at $38.5^{\circ} \mathrm{C}(\mathrm{P}<0.01$; Figure 2C, Table 2). Peak values and growth rates for IL6ST were similar in COCs matured at 38.5 and $41.0^{\circ} \mathrm{C}$ (Table 2 ).

\section{Relative abundance of Leukemia Inhibitory Factor (LIF)}

Relative abundance of LIF transcript changed over time $(P<0.0001$, Figure 3$)$ but was not affected by maturation temperature. Soon after collection and placement of COCs in maturation medium, LIF levels increased up through 8 hIVM. After 10 hIVM LIF levels decreased and by 12 hIVM, relative abundance was similar to values obtained at 2, 4 and 6 hIVM.

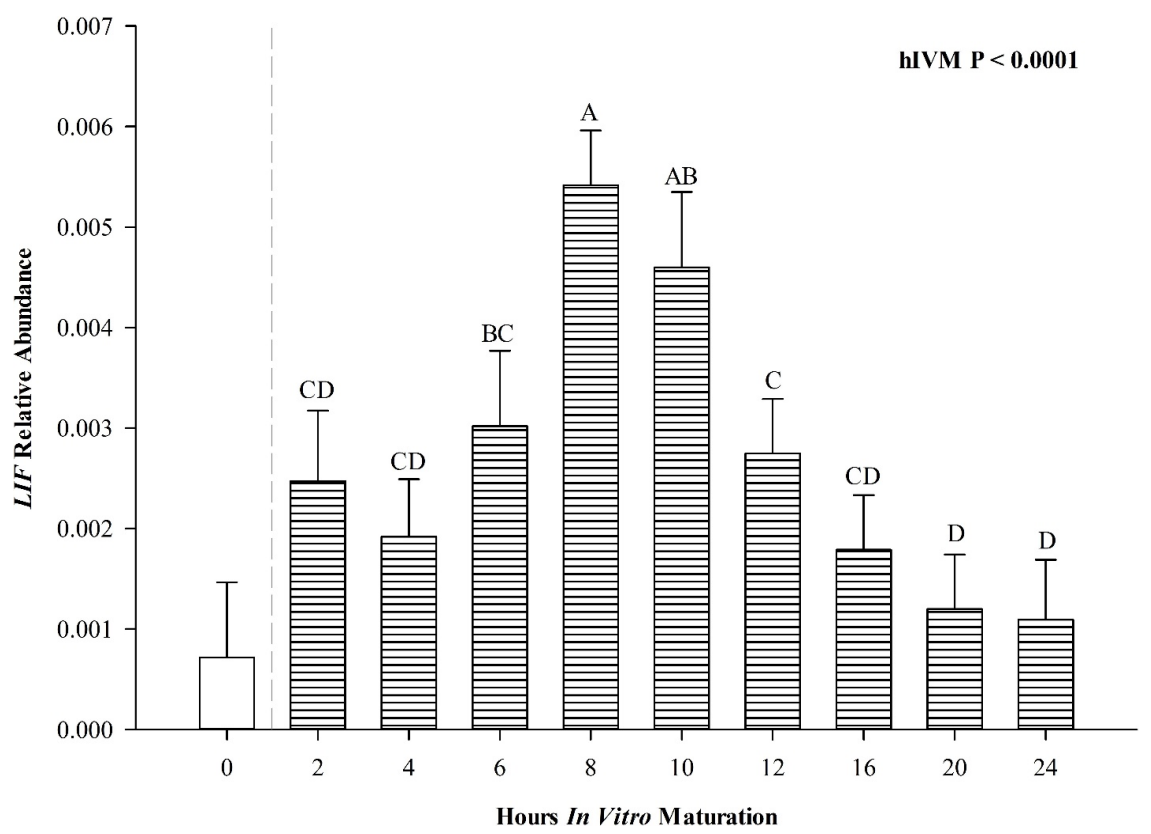

Figure 3. Relative abundance of LIF in cumulus-oocyte complexes during maturation, 0 hIVM not included in analysis but as a visual representation of a starting point, averaged across maturation temperatures presented as least squares means \pm SEM. ${ }^{A-D}$ means differ $P<0.0001$. 


\section{Progesterone production}

Progesterone released per COC into the maturation medium differed depending on IVM temperature and hIVM (Temp $x$ hIVM interaction, $\mathrm{P}=0.01$; Figure $4 \mathrm{~A}$ ). When all time points were included in the model ( 2 to 24 hIVM), heat-induced increases in progesterone produced per COC were most prominent at 20 and 24 hIVM (Figure 4A). When including only the time periods when IL6 levels were shifted by direct exposure to $41.0^{\circ} \mathrm{C}$ (i.e., 2 to 8 hIVM), progesterone produced per COC was only affected by IVM temperature and hIVM (i.e., no interaction; heat induced differences were not influenced by time; Figure 4B). To this end, progesterone per COC was 45.7 vs $54.9 \mathrm{pg}$ when COCs were matured at 38.5 and $41.0^{\circ} \mathrm{C}$, respectively $(P=0.002)$. Independent of temperature but related to time (hIVM), progesterone per COC was $12.7,40.7,63.2$ and 84.5 pg at $2,4,6$ and 8 hIVM, respectively $(P<0.0001)$.

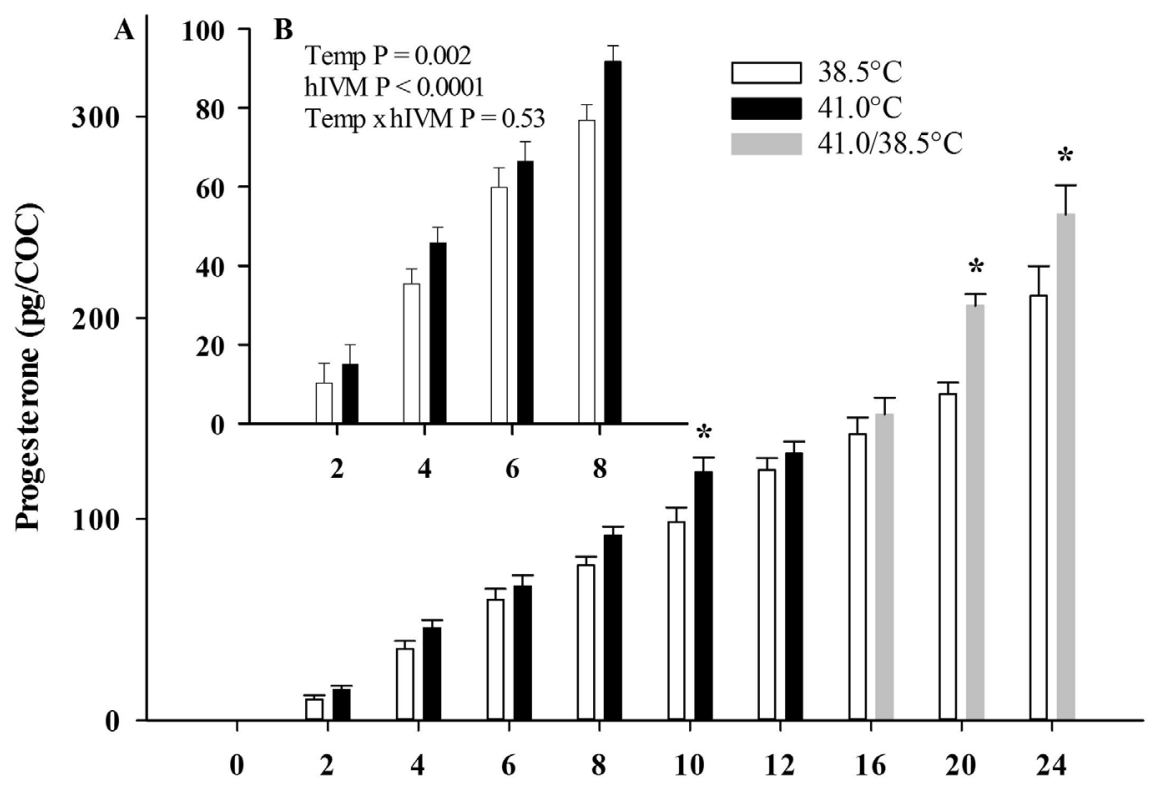

Hours In Vitro Maturation

Figure 4. Average progesterone produced per cumulus-oocyte complex (COC) during in vitro maturation (IVM) at $38.5^{\circ} \mathrm{C}$ or $41.0^{\circ} \mathrm{C}$ as measured in conditioned medium. COCs underwent IVM for up to $24 \mathrm{~h}$ at $38.5^{\circ} \mathrm{C}$ or $41.0^{\circ} \mathrm{C}$ (first 12 hours; $38.5^{\circ} \mathrm{C}$ thereafter). (A) Temperature $x$ hIVM P $=0.012$; * denotes heatinduced increase in progesterone at indicated time point (B) Impact of $41.0^{\circ} \mathrm{C}$ on $\mathrm{COC}$ on progesterone production during time period when relative abundance of IL 6 was altered by $41.0^{\circ} \mathrm{C}$.

\section{Study two: embryo development after COC exposure to $41.0^{\circ} \mathrm{C}$ for first 4 or $6 \mathrm{hIVM}$}

Ability of COCs to cleave and develop to the blastocyst stage after being exposed to an acute, short-term heat shock of $41.0^{\circ} \mathrm{C}$ during the first 4 or $6 \mathrm{hIVM}$ was similar to COCs matured at $38.5^{\circ} \mathrm{C}$ (Table 3). Stage and quality of blastocyst stage embryos from COCs matured at 38.5 or $41.0^{\circ} \mathrm{C}$ were similar. Number of nuclei in blastocyst stage embryos did not differ when originating from COCs matured at $38.5^{\circ} \mathrm{C}$ for $24 \mathrm{~h}, 41^{\circ} \mathrm{C}$ for $4 \mathrm{hIVM}$ or $41^{\circ} \mathrm{C}$ for $6 \mathrm{hIVM}$ (Table 3 ).

Table 3. Impact of an acute exposure to $41.0^{\circ} \mathrm{C}$ for the first 4 or $6 \mathrm{~h}$ of in vitro maturation.

\begin{tabular}{|c|c|c|c|c|c|c|c|}
\hline Treatment & $\begin{array}{l}\text { No. } \\
\text { OMM}^{1}\end{array}$ & $\begin{array}{c}\text { Cleaved } \\
(\%)\end{array}$ & $\begin{array}{c}8 \text { to } 16-\text { cell } \\
(\%)\end{array}$ & $\begin{array}{c}\text { Blastocysts } \\
(\%)\end{array}$ & Stage & Quality & Nuclei \\
\hline $38.5^{\circ} \mathrm{C}-24 \mathrm{~h}$ & 454 & $68.87 \pm 3.48$ & $74.64 \pm 3.47$ & $23.81 \pm 2.77$ & $6.69 \pm 0.12$ & $1.79 \pm 0.12$ & $101.68 \pm 11.39$ \\
\hline $41.0^{\circ} \mathrm{C}-4 \mathrm{~h}^{*}$ & 444 & $74.77 \pm 3.19$ & $75.19 \pm 3.39$ & $29.61 \pm 3.08$ & $6.75 \pm 0.12$ & $1.96 \pm 0.12$ & $118.76 \pm 11.39$ \\
\hline $41.0^{\circ} \mathrm{C}-6 \mathrm{~h}^{*}$ & 440 & $75.62 \pm 3.07$ & $65.88 \pm 3.78$ & $27.73 \pm 2.92$ & $6.64 \pm 0.12$ & $1.74 \pm 0.12$ & $116.07 \pm 11.39$ \\
\hline P-val & & 0.1426 & 0.0714 & 0.2558 & 0.6006 & 0.1586 & 0.4313 \\
\hline
\end{tabular}

*Exposed to $41.0^{\circ} \mathrm{C}$ for 4 or $6 \mathrm{~h}$ at onset of maturation period followed by $38.5^{\circ} \mathrm{C}$ for a total of $24 \mathrm{~h} .{ }^{1} \mathrm{Number}$ of $\mathrm{COCs}$ placed in maturation medium (OMM) for indicated treatment 


\section{Discussion}

Novel findings described herein provide further insight related to $I L 6$ and its receptor signaling component transcripts in the bovine cumulus-oocyte complex as it undergoes in vitro maturation. Examination at frequent time intervals confirmed temporal expression of $I L 6$ and IL6ST to the first 12 hours. Interestingly, the major impact of an acute, short-term exposure to $41.0^{\circ} \mathrm{C}$ was to shift the timing of IL6 and IL6ST expression. Specifically, peak IL6 levels in COCs exposed to an acute heat shock of $41.0^{\circ} \mathrm{C}$ occurred $\sim 2$ hours earlier than thermoneutral COCs. Regarding impact on IL6ST expression, peak levels in COCs exposed to $41.0^{\circ} \mathrm{C}$ occurred $\sim 1.5$ hours earlier than thermoneutral COCs. Functional significance of these findings remains unclear, but heat-related shifts in IL6 and IL6ST expression may explain heat-induced hastening of meiotic maturation reported previously by our laboratory.

Specific to the COC, both the oocyte and its associated cumulus produce IL6 (bovine: (Tscherner et al., 2018), human: (Zolti et al., 1991; Machelon et al., 1994), murine: (Liu et al., 2009), ovine: (Zhao et al., 2012)). Our study demonstrated that the IL6 transcript is minimally detectable in germinal vesicle (GV) stage COCs soon after removal from antral follicles. Transcript levels are higher by 2 hIVM and peak at 6.44 hours in bovine COCs matured at $38.5^{\circ} \mathrm{C}$. Levels decrease thereafter and remain low for remainder of maturation. Collectively findings of the study described herein document temporal expression of IL6 in the bovine during the first part of maturation and extend the findings of Tscherner et al. (2018) who examined IL6 abundance in bovine COCs at only three time periods (0, 7, and 24 hIVM). Consistent with our findings in the bovine, IL6 was present at low levels in ovine COCs soon after removal from antral follicles (Zhao et al., 2012) with peak expression noted at 4 hIVM; levels decreased thereafter. Use of Western blot confirmed presence of the IL6 protein in ovine COCs soon after removal from the antral follicle with highest levels at 4 and 8 hIVM (Zhao et al., 2012).

Regarding the potential for COC-derived IL6 to be impactful at the level of the cumulusoocyte complex, outcomes of study one show that IL 6 receptor abundance is greatest when IL 6 levels are markedly increasing during the first 6 hIVM. Furthermore, receptor levels are lowest during the latter half of maturation ( $12 \mathrm{~h}$ to $24 \mathrm{hIVM}$ ) when IL6 transcripts remain unchanged and are at low levels. Transcript abundance for the IL6 receptor relates well to protein levels in ovine COCs (Zhao et al., 2012) which has been localized to the oocyte surface (Zhao et al., 2012). Although receptor binding is important, intracellular signaling related to IL6 is dependent on forming a complex with IL6 signal transducer (Hibi et al., 1990; Mackiewicz et al., 1992; Heinrich et al., 2003; Wolf et al., 2014). Like IL6, IL6ST was temporally expressed during the first half of maturation, except peak levels occurred $\sim 2$ hours later. In murine COCs and hybridoma cells, addition of IL6 increases IL6ST transcript and protein levels (Canellada et al., 2008; Liu et al., 2009). Whether or not COC-derived increases in IL6 affect IL6ST expression in the bovine is unclear. Because of its importance after receptor binding, it is intuitive for IL6ST levels to peak and persist a bit longer than $I L 6$, which is what we observed in study one.

The presence of this multi-functional cytokine, its receptor, and associated signal transducer set the stage for IL6 to be playing an active and important role within the maturing COC. Although the specific factor(s) underlying the beginnings of maturation are not yet fully elucidated, an increase in COC-derived IL6 with levels peaking at or around 6 hIVM is likely a significant promotant of GV breakdown (GVBD). In other cell types, IL6 reduces gap junction permeability (Temme et al., 1998) which is requisite for GVBD. When murine COCs are cultured in a hypoxanthine-containing medium to inhibit spontaneous breakdown of the GV, addition of IL6 and its soluble receptor induced GVBD (Liu et al., 2009). Marked increases in COC-derived IL6 peaking at or around 6 hIVM in study one overlap with time period leading up to and when GVBD occurs (Hyttel et al., 1986; Edwards et al., 2005; Hooper et al., 2015; Campen et al., 2018). Interestingly, direct exposure to an elevated temperature of $41.0^{\circ} \mathrm{C}$ induces GVBD in bovine COCs (Edwards et al., 2005; Hooper et al., 2015; Campen et al., 2018) which is consistent with consequences of adding IL6 to meiotically inhibited oocytes (Liu et al., 2009). Heat-induced hastening of GVBD is detectable as early as 4 hIVM and more prominent by 6 hIVM (Hooper et al., 2015). Although factors triggering accelerated GVBD when activated by $41.0^{\circ} \mathrm{C}$ remain unclear, the heat-induced shift in the timing of IL6 expression and associated IL6ST by 
$\sim 1.5$ to 2 hours (study one) supports the notion for IL6 to be a contributing factor in the heatinduced hastening of GVBD previously reported (Edwards et al., 2005; Hooper et al., 2015; Campen et al., 2018).

Leukemia inhibitory factor, a member of the IL6 family (Nicola and Babon, 2015), promotes oocyte maturation in multiple species (Dang-Nguyen et al., 2014; Mo et al., 2014; Wang et al., 2019). Unlike IL6, there was no impact of $41.0^{\circ} \mathrm{C}$ on LIF expression at any time period examined. Although LIF levels increased during the first part of maturation (up through 8 to $10 \mathrm{hIVM}$ ) and decreased thereafter, highest levels were reached $\sim 2$ hours after IL6 peaked similar to temporal changes observed herein for IL6ST. Both IL6 and LIF depend on IL6ST for receptor-mediated signal transduction, though IL6 complexed with its receptor has higher affinity for IL6ST when both ligands are present (Gearing et al., 1991; Tscherner et al., 2018). Thus, temporal production of LIF coinciding with signal transducer expression may be important to influence other developmentally important events for maturation success (e.g., metaphase I and metaphase II progression).

Cumulus-derived progesterone released into the maturation medium increases soon after placement of COCs into medium and continues to increase throughout maturation (Study one, Rispoli et al., 2013; Campen et al., 2018). When examining just the time periods when IL6 levels were shifted by direct exposure to $41.0^{\circ} \mathrm{C}$ (i.e., 2 to $8 \mathrm{hIVM}$ ), COCs released more progesterone into maturation medium ( 45.7 vs $54.9 \mathrm{pg}$ for control and heat stress, respectively). Similar findings were previously reported by Campen et al. (2018). Blocking progesterone's ability to bind to its receptor using RU486 prevented FSH-induction of IL6 in murine oocytes (Liu et al., 2009) suggesting that progesterone may be a contributory factor helping modulate IL6 production.

Mindful that prolonged exposure (12 or more hours) is detrimental to embryo development (Edwards and Hansen, 1996; Lawrence et al., 2004; Roth and Hansen, 2004a, b; Edwards et al., 2005; Castro and Hansen, 2007; Schrock et al., 2007; Sugiyama et al., 2007; Edwards et al., 2009; Soto and Smith, 2009; Zhandi et al., 2009), an additional study was conducted to examine developmental consequences of $41.0^{\circ} \mathrm{C}$ when occurring at the beginning of oocyte maturation but for shorter time periods (i.e., first 4 or 6 hIVM). When utilizing COCs collected from antral follicles during the latter part of fall, winter, and through late spring to avoid developmental issues related to summer heat stress (reviewed by Wolfenson and Roth, 2019), blastocyst development was not impaired by $41.0^{\circ} \mathrm{C}$. In fact, blastocyst development, stage and quality scores, and nuclei numbers were numerically higher when COCs where acutely exposed to a higher than normal temperature of $38.5^{\circ} \mathrm{C}$.

In retrospect, absence of a negative effect on embryo development after direct exposure of naiive COCs to an acute-short term heat "shock" is not surprising when occurring at or near the onset of oocyte maturation. Body temperature of females exhibiting estrus is often elevated as a result of heightened levels of sexual activity (Lewis and Newman, 1984; Kyle et al., 1998; Piccione et al., 2003; Fisher et al., 2008; Suthar et al., 2011; Miura et al., 2017; Randi et al., 2018; Higaki et al., 2019). Peak temperature typically occurs at or around the LH surge (Rajamahendran et al., 1989; Mosher et al., 1990; Fisher et al., 2008) which is important to induce ovulation and maturation of the oocyte resident within the ovulatory follicle.

\section{Conclusion}

In summary, heat-induced shift in the temporal production of IL 6 along with its impact on progesterone likely cooperate in heat-induced hastening of meiotic progression described by others. Given potency of an acute exposure to directly alter components important to promote meiotic maturation, it is not surprising that elevated body temperature occurring at inappropriate and for extended time periods during chronic periods of summer heat stress or disease reduce pregnancy outcomes by directly affecting cumulus-oocyte components. 


\section{Acknowledgements}

This project was supported by Agriculture and Food Research Initiative Competitive Grant $n^{\circ}$. 2016-67015-24899 from the USDA National Institute of Food and Agriculture, the state of Tennessee through UT AgResearch, East Tennessee Research and Education Center, the Department of Animal Science, and the USDA National Institute of Food and Agriculture, Hatch Project N ${ }^{\circ} .1015707$ and 1022068. The authors would like to thank Xiaocun Sun from Research Computing Support in OIT at the University of Tennessee for her assistance with JMP analysis. The authors would like to thank Hunter Liles, Abigayle Pollock, and Mary Ali Oliver for their time spent in travel to the abattoir where the much-appreciated efforts of Russell Harris (Brown Packing (o., Inc) allowed for obtaining ovaries. The authors also wish to thank DeSoto Biosciences for providing ovaries to obtain COCs for primer optimization.

\section{References}

Armstrong DV. Heat stress interaction with shade and cooling. J Dairy Sci. 1994;77(7):2044-50. http://dx.doi.org/10.3168/jds.S0022-0302(94)77149-6. PMid:7929964.

Assidi M, Dieleman SJ, Sirard MA. Cumulus cell gene expression following the LH surge in bovine preovulatory follicles: potential early markers of oocyte competence. Reproduction. 2010;140(6):83552. http://dx.doi.org/10.1530/REP-10-0248. PMid:20724459.

Botigelli RC, Razza EM, Pioltine EM, Fontes PK, Schwarz KRL, Leal CLV, Nogueira MFG. Supplementing in vitro embryo production media by NPPC and sildenafil affect the cytoplasmic lipid content and gene expression of bovine cumulus-oocyte complexes and embryos. Reprod Biol. 2018;18(1):66-75. http://dx.doi.org/10.1016/j.repbio.2018.01.004. PMid:29361408.

Campen KA, Abbott CR, Rispoli LA, Payton RR, Saxton AM, Edwards JL. Heat stress impairs gap junction communication and cumulus function of bovine oocytes. J Reprod Dev. 2018;64(5):385-92. http://dx.doi.org/10.1262/jrd.2018-029. PMid:29937465.

Canellada A, Alvarez I, Berod L, Gentile T. Estrogen and progesterone regulate the IL- 6 signal transduction pathway in antibody secreting cells. J Steroid Biochem Mol Biol. 2008;111(3-5):255-61. http://dx.doi.org/10.1016/j.jsbmb.2008.06.009. PMid:18619543.

Castro EPLA, Hansen PJ. Interactions between oxygen tension and glucose concentration that modulate actions of heat shock on bovine oocytes during in vitro maturation. Theriogenology. 2007;68(5):76370. http://dx.doi.org/10.1016/j.theriogenology.2007.06.005. PMid:17643482.

Clark A, Matos DG, Jackson JA, Palmer SS, Tran CAT. Use of IL-6 type cytokines for maturation of oocytes. United States Patent. Appl. No. 10/998,080:Patent No. 8,071,375 B072. 2011.

Dang-Nguyen TQ, Haraguchi S, Kikuchi K, Somfai T, Bodó S, Nagai T. Leukemia inhibitory factor promotes porcine oocyte maturation and is accompanied by activation of signal transducer and activator of transcription 3. Mol Reprod Dev. 2014;81(3):230-9. http://dx.doi.org/10.1002/mrd.22289. PMid:24307388.

del Collado M, Silveira JC, Sangalli JR, Andrade GM, Sousa LRDS, Silva LA, Meirelles FV, Perecin F. Fatty acid binding protein 3 and transzonal projections are involved in lipid accumulation during in vitro maturation of bovine oocytes. Sci Rep. 2017;7(1):2645. http://dx.doi.org/10.1038/s41598-017-024679. PMid:28572619.

Dunlap S, Vincent C. Influence of postbreeding thermal stress on conception rate in beef cattle. J Anim Sci. 1971;32(6):1216-8. http://dx.doi.org/10.2527/jas1971.3261216x. PMid:5087369.

Ealy AD, Drost M, Hansen PJ. Developmental changes in embryonic resistance to adverse effects of maternal heat stress in cows. J Dairy Sci. 1993;76(10):2899-905. http://dx.doi.org/10.3168/jds.S00220302(93)77629-8. PMid:8227617.

Edwards JL, Bogart AN, Rispoli LA, Saxton AM, Schrick FN. Developmental competence of bovine embryos from heat-stressed ova. J Dairy Sci. 2009;92(2):563-70. http://dx.doi.org/10.3168/jds.20081495. PMid:19164666.

Edwards JL, Hansen PJ. Elevated temperature increases heat shock protein 70 synthesis in bovine twocell embryos and compromises function of maturing oocytes. Biol Reprod. 1996;55(2):340-6. http://dx.doi.org/10.1095/biolreprod55.2.341. PMid:8828838. 
Edwards JL, Saxton AM, Lawrence JL, Payton RR, Dunlap JR. Exposure to a physiologically relevant elevated temperature hastens in vitro maturation in bovine oocytes. J Dairy Sci. 2005;88(12):4326-33. http://dx.doi.org/10.3168/jds.S0022-0302(05)73119-2. PMid:16291624.

Elvinger F, Hansen P, Natzke R. Modulation of function of bovine polymorphonuclear leukocytes and lymphocytes by high temperature in vitro and in vivo. Am J Vet Res. 1991;52(10):1692-8. PMid:1662922.

Fallon G. Body temperature and fertilization in the cow. J Reprod Fertil. 1962;3(1):116-23. http://dx.doi.org/10.1530/jrf.0.0030116. PMid:13891471.

Faundez R, Kawecka O, Aniołek O, Petrajtis-Gołobów M, Karska D, Gajewski Z. The influence of GM-CSF, IL-6 and TGF-a on in vitro maturation of porcine oocytes. Reprod Domest Anim. 2015;50:51-2.

Faundez R, Kawecka O, Karska D, Petrajtis M, Gajewski Z. The influence of GM-CSF, IL-6 and TGF-a on the in vitro maturation of bovine oocytes. Reprod Domest Anim. 2014;49:63.

Fisher AD, Morton R, Dempsey JM, Henshall JM, Hill JR. Evaluation of a new approach for the estimation of the time of the LH surge in dairy cows using vaginal temperature and electrodeless conductivity measurements. Theriogenology. 2008;70(7):1065-74. http://dx.doi.org/10.1016/j.theriogenology.2008.06.023. PMid:18639924.

Gaalaas R. Effect of atmospheric temperature on body temperature and respiration rate of Jersey cattle. J Dairy Sci. 1945;28(7):555-63. http://dx.doi.org/10.3168/jds.S0022-0302(45)95208-8.

Gearing D, Thut C, VandeBos T, Gimpel S, Delaney P, King J, Price V, Cosman D, Beckmann M. Leukemia inhibitory factor receptor is structurally related to the IL-6 signal transducer, gp130. EMBO J. 1991;10(10):2839-48. http://dx.doi.org/10.1002/j.1460-2075.1991.tb07833.x. PMid:1915266.

Heinrich PC, Behrmann I, Haan S, Hermanns HM, Muller-Newen G, Schaper F. Principles of interleukin (IL)-6-type cytokine signalling and its regulation. Biochem J. 2003;374(Pt 1):1-20. http://dx.doi.org/10.1042/bj20030407. PMid:12773095.

Hibi M, Murakami M, Saito M, Hirano T, Taga T, Kishimoto T. Molecular cloning and expression of an IL-6 signal transducer, gp130. Cell. 1990;63(6):1149-57. http://dx.doi.org/10.1016/0092-8674(90)90411-7. PMid:2261637.

Higaki S, Miura R, Suda T, Andersson LM, Okada H, Zhang Y, Itoh T, Miwakeichi F, Yoshioka K. Estrous detection by continuous measurements of vaginal temperature and conductivity with supervised machine learning in cattle. Theriogenology. 2019;123:90-9. http://dx.doi.org/10.1016/j.theriogenology.2018.09.038. PMid:30292860.

Hooper LM, Payton RR, Rispoli LA, Saxton AM, Edwards JL. Impact of heat stress on germinal vesicle breakdown and lipolytic changes during in vitro maturation of bovine oocytes. J Reprod Dev. 2015;61(5):459-64. http://dx.doi.org/10.1262/jrd.2014-168. PMid:26120041.

Hyttel P, Xu K, Smith S, Greve T. Ultrastructure of in-vitro oocyte maturation in cattle. J Reprod Fertil. 1986;78(2):615-25. http://dx.doi.org/10.1530/jrf.0.0780615. PMid:3806520.

Kyle BL, Kennedy AD, Small JA. Measurement of vaginal temperature by radiotelemetry for the prediction of estrus in beef cows. Theriogenology. 1998;49(8):1437-49. http://dx.doi.org/10.1016/S0093-691X(98)00090-9. PMid:10732008.

Lawrence JL, Payton RR, Godkin JD, Saxton AM, Schrick FN, Edwards JL. Retinol improves development of bovine oocytes compromised by heat stress during maturation. J Dairy Sci. 2004;87(8):2449-54. http://dx.doi.org/10.3168/jds.S0022-0302(04)73368-8. PMid:15328267.

Lewis GS, Newman SK. Changes throughout estrous cycles of variables that might indicate estrus in dairy cows. J Dairy Sci. 1984;67(1):146-52. http://dx.doi.org/10.3168/jds.S0022-0302(84)81278-3. PMid:6538581.

Liu Z, Matos DG, Fan H-Y, Shimada M, Palmer S, Richards JS. Interleukin-6: an autocrine regulator of the mouse cumulus cell-oocyte complex expansion process. Endocrinology. 2009;150(7):3360-8. http://dx.doi.org/10.1210/en.2008-1532. PMid:19299453.

Macabelli CH, Ferreira RM, Gimenes LU, de Carvalho NAT, Soares JG, Ayres H, Ferraz ML, Watanabe YF, Watanabe OY, Sangalli JR, Smith LC, Baruselli PS, Meirelles FV, Chiaratti MR. Reference gene selection for gene expression analysis of oocytes collected from dairy cattle and buffaloes during winter and summer. PLoS One. 2014;9(3):e93287. http://dx.doi.org/10.1371/journal.pone.0093287. PMid:24676354.

Machelon V, Emilie D, Lefevre A, Nome F, Durand-Gasselin I, Testart J. Interleukin-6 biosynthesis in human preovulatory follicles: some of its potential roles at ovulation. J Clin Endocrinol Metab. 1994;79(2):633-42. PMid:7519193. 
Mackiewicz A, Schooltink H, Heinrich PC, Rose-John S. Complex of soluble human IL-6-receptor/IL-6 upregulates expression of acute-phase proteins. J Immunol. 1992;149(6):2021-7. PMid:1381393.

Miura R, Yoshioka K, Miyamoto T, Nogami H, Okada H, Itoh T. Estrous detection by monitoring ventral tail base surface temperature using a wearable wireless sensor in cattle. Anim Reprod Sci. 2017;180:50-7. http://dx.doi.org/10.1016/j.anireprosci.2017.03.002. PMid:28330768.

Mo X, Wu G, Yuan D, Jia B, Liu C, Zhu S, Hou Y. Leukemia inhibitory factor enhances bovine oocyte maturation and early embryo development. Mol Reprod Dev. 2014;81(7):608-18. http://dx.doi.org/10.1002/mrd.22327. PMid:24687528.

Mosher M, Ottobre J, Haibel G, Zartman D. Estrual rise in body temperature in the bovine II. The temporal relationship with ovulation. Anim Reprod Sci. 1990;23(2):99-107. http://dx.doi.org/10.1016/0378-4320(90)90052-H.

Nicola NA, Babon JJ. Leukemia inhibitory factor (LIF). Cytokine Growth Factor Rev. 2015;26(5):533-44. http://dx.doi.org/10.1016/j.cytogfr.2015.07.001. PMid:26187859.

Pavani KC, Rocha A, Baron E, Lourenço J, Faheem M, Silva FM. The effect of kinetic heat shock on bovine oocyte maturation and subsequent gene expression of targeted genes. Zygote. 2017;25(3):383-9. http://dx.doi.org/10.1017/S0967199417000223. PMid:28592345.

Piccione G, Caola G, Refinetti R. Daily and estrous rhythmicity of body temperature in domestic cattle. BMC Physiol. 2003;3(1):7. http://dx.doi.org/10.1186/1472-6793-3-7. PMid:12882649.

Rajamahendran R, Robinson J, Desbottes S, Walton JS. Temporal relationships among estrus, body temperature, milk yield, progesterone and luteinizing hormone levels, and ovulation in dairy cows. Theriogenology. 1989;31(6):1173-82. http://dx.doi.org/10.1016/0093-691X(89)90086-1. PMid:16726635.

Randi F, McDonald M, Duffy P, Kelly AK, Lonergan P. The relationship between external auditory canal temperature and onset of estrus and ovulation in beef heifers. Theriogenology. 2018;110:175-81. http://dx.doi.org/10.1016/j.theriogenology.2018.01.001. PMid:29407899.

Regassa A, Rings F, Hoelker M, Cinar U, Tholen E, Looft C, Schellander K, Tesfaye D. Transcriptome dynamics and molecular cross-talk between bovine oocyte and its companion cumulus cells. BMC Genomics. 2011;12(1):57. http://dx.doi.org/10.1186/1471-2164-12-57. PMid:21261964.

Rispoli LA, Edwards JL, Pohler KG, Russell S, Somiari RI, Payton RR, Schrick FN. Heat-induced hyperthermia impacts the follicular fluid proteome of the periovulatory follicle in lactating dairy cows. PLoS One. 2019;14(12):e0227095. http://dx.doi.org/10.1371/journal.pone.0227095. PMid:31887207.

Rispoli LA, Lawrence JL, Payton RR, Saxton AM, Schrock GE, Schrick FN, Middlebrooks BW, Dunlap JR, Parrish JJ, Edwards JL. Disparate consequences of heat stress exposure during meiotic maturation: embryo development after chemical activation vs fertilization of bovine oocytes. Reproduction. 2011;142(6):831-43. http://dx.doi.org/10.1530/REP-11-0032. PMid:21994359.

Rispoli LA, Payton RR, Gondro C, Saxton AM, Nagle KA, Jenkins BW, Schrick FN, Edwards JL. Heat stress effects on the cumulus cells surrounding the bovine oocyte during maturation: altered matrix metallopeptidase 9 and progesterone production. Reproduction. 2013;146(2):193-207. http://dx.doi.org/10.1530/REP-12-0487. PMid:23744615.

Roman-Ponce $\mathrm{H}$, Thatcher W, Buffington D, Wilcox C, Van Horn H. Physiological and production responses of dairy cattle to a shade structure in a subtropical environment. J Dairy Sci. 1977;60(3):424-30. http://dx.doi.org/10.3168/jds.S0022-0302(77)83882-4.

Roth Z, Hansen PJ. Involvement of apoptosis in disruption of developmental competence of bovine oocytes by heat shock during maturation. Biol Reprod. 2004a;71(6):1898-906. http://dx.doi.org/10.1095/biolreprod.104.031690. PMid:15306551.

Roth Z, Hansen PJ. Sphingosine 1-phosphate protects bovine oocytes from heat shock during maturation. Biol Reprod. 2004b;71(6):2072-8. http://dx.doi.org/10.1095/biolreprod.104.031989. PMid:15317688.

Schrock GE, Saxton AM, Schrick FN, Edwards JL. Early in vitro fertilization improves development of bovine ova heat stressed during in vitro maturation. J Dairy Sci. 2007;90(9):4297-303. http://dx.doi.org/10.3168/jds.2007-0002. PMid:17699049.

Seath D, Miller $G$. The relative importance of high temperature and high humidity as factors influencing respiration rate, body temperature, and pulse rate of dairy cows. J Dairy Sci. 1946;29(7):465-72. http://dx.doi.org/10.3168/jds.S0022-0302(46)92502-7. 
Soto $\mathrm{P}$, Smith LC. BH4 peptide derived from Bcl-xL and Bax-inhibitor peptide suppresses apoptotic mitochondrial changes in heat stressed bovine oocytes. Mol Reprod Dev. 2009;76(7):637-46. http://dx.doi.org/10.1002/mrd.20986. PMid:19062170.

Sugiyama S, McGowan M, Phillips N, Kafi M, Young M. Effects of increased ambient temperature during IVM and/or IVF on the in vitro development of bovine zygotes. Reprod Domest Anim. 2007;42(3):2714. http://dx.doi.org/10.1111/j.1439-0531.2006.00776.x. PMid:17506805.

Suthar VS, Burfeind O, Patel JS, Dhami AJ, Heuwieser W. Body temperature around induced estrus in dairy cows. J Dairy Sci. 2011;94(5):2368-73. http://dx.doi.org/10.3168/jds.2010-3858. PMid:21524526.

Temme A, Traub O, Willecke K. Downregulation of connexin32 protein and gap-junctional intercellular communication by cytokine-mediated acute-phase response in immortalized mouse hepatocytes. Cell Tissue Res. 1998;294(2):345-50. http://dx.doi.org/10.1007/s004410051184. PMid:9799450.

Tscherner A, Brown AC, Stalker L, Kao J, Dufort I, Sirard M-A, LaMarre J. STAT3 signaling stimulates miR21 expression in bovine cumulus cells during in vitro oocyte maturation. Sci Rep. 2018;8(1):11527. http://dx.doi.org/10.1038/s41598-018-29874-w. PMid:30068990.

Turner $\mathrm{H}$. Genetic variation of rectal temperature in cows and its relationship to fertility. Anim Sci. 1982;35(3):401-12. http://dx.doi.org/10.1017/S0003356100001094.

Ulberg LC, Burfening PJ. Embryo death resulting from adverse environment on spermatozoa or ova. J Anim Sci. 1967;26(3):571-7. http://dx.doi.org/10.2527/jas1967.263571x. PMid:6068502.

Wang J, Liu Z, Sun Q, Xia S, Cui J, Yang L, An L, Zhang J, Su L, Su Y, Du F. Combined treatment with cysteamine and leukemia inhibitory factor promotes guinea pig oocyte meiosis in vitro. Am J Transl Res. 2019;11(12):7479-91. PMid:31934295.

Wang Y, Liang N, Yao G, Tian H, Zhai Y, Yin Y, Sun F. Knockdown of TrkA in cumulus oocyte complexes (COCs) inhibits EGF-induced cumulus expansion by down-regulation of IL-6. Mol Cell Endocrinol. 2014;382(2):804-13. http://dx.doi.org/10.1016/j.mce.2013.10.031. PMid:24215827.

Wolf J, Rose-John S, Garbers C. Interleukin-6 and its receptors: a highly regulated and dynamic system. Cytokine. 2014;70(1):11-20. http://dx.doi.org/10.1016/j.cyto.2014.05.024. PMid:24986424.

Wolfenson D, Roth Z. Impact of heat stress on cow reproduction and fertility. Anim Front. 2019;9(1):32-8. http://dx.doi.org/10.1093/af/vfy027. PMid:32002237.

Wooldridge LK, Ealy AD. Interleukin-6 increases inner cell mass numbers in bovine embryos. BMC Dev Biol. 2019;19(1):2. http://dx.doi.org/10.1186/s12861-019-0182-z. PMid:30709330.

Zakari A, Molokwu E, Osori D. Effects of rectal and ambient temperatures and humidity on conception rates. Theriogenology. 1981;16(3):331-6. http://dx.doi.org/10.1016/0093-691X(81)90017-0. PMid:16725645.

Zhandi M, Towhidi A, Nasr-Esfahani MH, Eftekhari-Yazdi P, Zare-Shahneh A. Unexpected detrimental effect of insulin like growth factor-1 on bovine oocyte developmental competence under heat stress. J Assist Reprod Genet. 2009;26(11-12):605-11. http://dx.doi.org/10.1007/s10815-009-9364-0. PMid:19915974.

Zhao X, Cang M, Gao X-y, Yang M, Yuan J, Zhu B, Wang Z, Liu D. Expression of interleukin-6 and interleukin-6 receptor in ovine oocytes during in vitro maturation. J Integr Agric. 2012;11(8):1333-9. http://dx.doi.org/10.1016/S2095-3119(12)60131-2.

Zolti M, Ben-Rafael Z, Meirom R, Shemesh M, Bider D, Mashiach S, Apte RN. Cytokine involvement in oocytes and early embryos. Fertil Steril. 1991;56(2):265-72. http://dx.doi.org/10.1016/S00150282(16)54483-5. PMid:2070856.

\section{Author contributions}

JRR: Formal analysis, Investigation, Validation, Visualization, Writing - original draft and editing; LAR: Conceptualization, Data Curation, Formal analysis, Investigation, Methodology, Project administration, Supervision, Validation, Visualization, Writing - review \& editing; RRP: Conceptualization, Data Curation, Formal analysis, Investigation, Methodology, Project administration, Supervision, Validation, Visualization, Writing - original draft and editing; LGS: Formal analysis, Resources, Software, Visualization, Writing - review \& editing; FNS: Conceptualization, Visualization, Writing - review \& editing; KJM: Visualization, Writing - review \& editing; JLE: Conceptualization, Data Curation, Formal analysis, Funding Acquisition, Methodology, Project administration, Resources, Supervision, Validation, Visualization, Writing - original draft and editing. 